\title{
Risk Factors of Pneumonia in Children under Five in Lewoleba Hospital, East Nusa Tenggara, Indonesia
}

\author{
Nikosius Dae Sory Wutun, M Dinah Charlota Lerik, Muntasir
}

\author{
Nusa Cendana University
}

\section{ABSTRACT}

Background: Pneumonia is an infection of the respiratory system, especially the lungs, which is associated with increased fluid in the alveoli followed by fever and rapid breathing. Under-five pneumonia sufferers in Indonesia in 2017 reached 447,431 cases (46.34\%) and caused death in 1,351 under-five sufferers. The study aimed to determine the risk factors for the incidences of pneumonia in children at Regional Public Hospital of Lewoleba, East Nusa Tenggara, Indonesia Subjects and Method: This was a cross-sectional study conducted at the Lewoleba Regional Hospital in 2020. The population of the study was 1,023 toddlers. This study used purposive sampling to select a sample of 126 toddlers. The dependent variable of this study was pneumonia. The independent variable of this study was the history of asthma. Data were collected by a questionnaire and analyzed by a multiple logistic regressions.
Results: Had history of asthma and cigarette smoke exposure increased the risk of pneumonia $(\mathrm{p}<0.001)$.

Conclusion: Has history of asthma and cigarette smoke exposure increased the risk of pneumonia. Children with a history of asthma have a risk of having respiratory disorders, impaired mucus and ciliated cell integrity, and decreased local and systemic humoral / cellular immunity.

Keywords: pneumonia, history of asthma, children under five

\section{Correspondence:}

Nikosius Dae Sory Wutun, Universitas Negeri Nusa Cendana Kupang. Jl.Adisucipto Penfui, Kupang, NTT. nichosiusdae94@gmail.com, 082340482420

\section{Cite this as:}

Wutun NDS, Lerik MDC, Muntasir (2020). Risk Factors of Pneumonia in Children under Five in Lewoleba Hospital, East Nusa Tenggara, Indonesia. J Epidemiol Public Health. 05(02): 218-226. https://doi.org/10.26911/jepublichealth.2020.05.02.09.

(c) (i) (-) Journal of Epidemiology and Public Health is licensed under a Creative Commons (c) ${ }_{\mathrm{EY}}$ NG SA Attribution-Non Commercial-Share Alike 4.0 International License.

\section{BACKGROUND}

Pneumonia is an infection of the respiratory system, especially the lungs which is associated with increased fluid in the alveoli, followed by fever and rapid breathing (Taqiyyah and Jouhar, 2013). Pneumonia occurs due to bacteria, viruses, or fungi. Pneumonia bacteria on children were haemophilus influenza type $\mathrm{b}$ and streptococcus pneumonia, while the virus that attacked pneumonia was the respiratory syncytial virus (WHO, 2016).

Children under two years old, individual over sixty-five years old, and individual who has malnutrition and immunological disorders is the indicators that susceptible to have pneumonia (Dinkes, 2017). Pneumonia was the most common cause of death among toddlers which was $16 \%$, it was estimated that 920,136 toddlers died from pneumonia in 2015 (WHO, 2016).

Most cases of pneumonia occurred in developing countries such as Southeast Asia $39 \%$ and Africa 30\%, which experienced the highest cases and severity of pneumonia in children (Zar et al., 2013). WHO (2016) stated that 15 countries had the highest mortality rates from pneumonia among children, where Indonesia was on the 8th rank in the 
world. Pneumonia is the second leading cause of death after diarrhea in Indonesia. Toddlers who suffered from pneumonia in Indonesia in 2017 reached 447,431 cases (46.34\%) and caused death in toddlers which were 1,351 (Ministry of Health RI, 2018).

The Health Profiles of Regencies / Cities in NTT Province showed that the scope of pneumonia finding and pneumonia treatment in toddlers had fluctuated from 20142017. In 2014 there were 3,714 cases (13\%), while in 2015 there were 3,079 cases (4.94\%), in 2016 there were 3,683 cases $(5.87 \%)$ and 2017 there were to 6,059 cases (9.99\%). There had been a decline in the finding and treatment of pneumonia sufferers (Profile of the NTT Health Office, 2017)

The estimated number of toddlers with pneumonia in a health center was based on the incidence rate of toddlers with pneumonia from the number of toddlers in that area. If the pneumonia incidence rate in certain areas is not known, the (national) estimate of the pneumonia incidence in toddlers in Indonesia can be used by calculating $10 \%$ from the total population of toddlers in Indonesia. The toddlers in Lembata Regency in 2016 were 11,820 children, from the total, it was estimated $10 \%$ had pneumonia. So the estimated number of pneumonia sufferers was 1,182 cases, with $18.6 \%$ of the cases found and treated or equivalent to 220 toddlers. The toddlers in Lembata Regency in 2017 were 10,870 , so it was estimated $10 \%$ from the total or equal to 1,087 toddlers had pneumonia, with the number of cases found and treated was $12.3 \%$ or equivalent to 134 toddlers. compared to 2016, pneumonia cases in children under five in the Lembata Regency in 2017 were lower with the difference was $6.3 \%$. It could be concluded that the case development of finding and treating toddlers with pneumonia cases was still the same in 2016 and 2017 from the total estimated cases. The scope of pneumonia findings in the Lem- bata Regency in 2017 which was $12.3 \%$ had not reached the determined national target of $80 \%$. This required attention from all parties, both program implementers and policymakers as well as the community (Lembata District Health Profile, 2017).

The risk factors that increase pneumonia experienced by toddlers are child factors, parent or caregiver factors which include education level, maternal knowledge about pneumonia, and treatment-seeking practices. Environmental factors include home environmental conditions such as a crowded house with occupants and indoor air pollution such as the use of firewood and the presence of families who smoke in the house (Anwar and Damayanti, 2014).

The role of health workers to improve maternal behavior can be in the form of carrying out health activities to prevent pneumonia, such as providing education through delivering information to mothers about pneumonia. However, health workers were still lacking educate mothers which were $52.4 \%$. This occured due to a lack of trained personnel for the management of pneumonia (Wahyuningsih et al., 2014). Besides the health workers, mothers also seek information about pneumonia through the media which is $1.6 \%$ and seek information from the closest people such as family or people around the home environment which is 38.8\% (Yahaya et al., 2018).

The study carried out by Najimi et al. (2013) about the effect of health education on mothers with feverish children showed that after health education there was an increase in knowledge which was 7.58, an increase in attitudes was 2.06, and an increase in maternal action on preventing febrile seizures in children was 2.46 .

The study conducted Novrianda et al. (2015) stated that after health education there was an increase in maternal knowledge from 11.87 to 13.80 and an increase in the 
ability of mothers to care for children with Acute Respiratory Infection (ARI) from 6.53 to 9.13. Health education is more effective in improving one's behavior.

\section{SUBJECTS AND METHOD}

1. Study Design

This was a cross-sectional study performed in Regional Public Hospital of Lewoleba, East Nusa Tenggara, from February to March 2020.

\section{Population dan Sample}

The study population was toddlers who had been treated in the Regional Public Hospital of Lewoleba in 2019. There were 1,023 toddlers in the hospital. A sample of 126 children was selected by purposive sampling.

\section{Study Variables}

The dependent variable was pneumonia. The independent variables were age, sex, history of breastfeeding, history of asthma, maternal knowledge, and smoking history of family members.

\section{Operational Definition of Variables}

Pneumonia is an infection of the respiratory tract. Severe pneumonia categories are indicated by cough and/or difficulty in breathing and at least one nostril exhalation, $\mathrm{X}$-ray, and chest wall pulling inward. Individuals categorized as pneumonia sufferers when it was determined by the doctor and register in the hospital. Non-pneumonia patients had no indications of pneumonia or severe diseases, and the doctor did not determine as pneumonia sufferers.

The age of toddlers was the age of children counted from they were born until the survey was conducted. It was calculated in years.

Sex was the different biological and physical characteristics between males and females which was not exchanged.
The History of Breastfeeding was the giving of exclusive breastfeeding for six months without providing additional food and drink to the baby.

History of Asthma was the history of children who ever suffered from asthma/ wheezing.

Maternal Knowledge was the knowledge of mother in answering the questions in the the questionnaire about the definition of pneumonia, the signs and symptoms, cause, danger, transmission, and prevention of pneumonia.

The History of Smoking the presence of family members who smoked and live together with the toddlers.

\section{Data Analysis}

Univariate analysis was carried out to count the frequency of every variable ( $\mathrm{n}$ and \%). Bivariate analysis was performed using the chisquare test.

\section{Research Ethics}

The researchers had considered some principles of research ethics in conducting the study namely the right to self-determination, the right to full disclosure, the right to privacy, the right to anonymity and confidentiality, the Right to fair treatment, and the right to protection from discomfort a harm.

\section{RESULTS}

A. Univariate Analysis

Tabel 1 showed frequency distribution based on age, sex, history of breastfeeding, history of asthma, maternal knowledge, smoking history of family members, and pneumonia.

Table 2 showed cross tabulation of pneumonia with gender, age, breastfeeding, history of asthma, maternal knowledge, and smoking history of family members. 
Wutun et al./ Risk Factors of Pneumonia in Children under Five

Table 1. Frequency distribution based on age, sex, history of breastfeeding, history of asthma, maternal knowledge, smoking history of family members, and pneumonia

\begin{tabular}{llcc}
\hline \multicolumn{1}{c}{ Variable } & & $\mathbf{N}$ & $\mathbf{\%}$ \\
\hline Age & 1 Year & 58 & 46.0 \\
& 2 Years & 33 & 26.2 \\
& 3 Years & 18 & 14.3 \\
& 4 Years & 8 & 6.3 \\
Sex & 5 Years & 9 & 7.1 \\
History of Breastfeeding & Female & 57 & 45.2 \\
& Male & 69 & 54.8 \\
History of Asthma & Not given breastfeeding & 6 & 4.8 \\
& Given Breastfeeding & 120 & 95.2 \\
Level of Maternal Knowledge & Have a history of asthma & 72 & 57.1 \\
& & & \\
\multirow{3}{*}{ Smoking history of family members } & Have no history of asthma & 54 & 42.9 \\
& Low & 67 & 53.2 \\
Incidences of Pneumonia & Medium & 20 & 15.9 \\
& Nigh & 39 & 31.0 \\
& No & 68 & 54.0 \\
& Pneumonia & 58 & 46.0 \\
& Non-Pneumonia & 63 & 50.0 \\
\hline
\end{tabular}

\section{B. Bivariate Analysis}

Table 2. Cross tabulation of pneumonia with gender, age, breastfeeding, history of asthma, maternal knowledge, and smoking history of family members

\begin{tabular}{|c|c|c|c|c|c|}
\hline \multirow{3}{*}{ Independent Variable } & \multicolumn{4}{|c|}{ Pneumonia } & \multirow{3}{*}{$\mathbf{p}$} \\
\hline & \multicolumn{2}{|c|}{ Yes } & \multicolumn{2}{|c|}{ No } & \\
\hline & $\mathbf{N}$ & $\%$ & $\mathbf{N}$ & $\%$ & \\
\hline \multicolumn{6}{|l|}{ Sex } \\
\hline Female & 25 & $19.8 \%$ & 32 & $25.4 \%$ & \multirow{2}{*}{0.210} \\
\hline Male & 38 & $30.2 \%$ & 31 & $24.6 \%$ & \\
\hline \multicolumn{6}{|l|}{ Age } \\
\hline 1 Year & 37 & $29.4 \%$ & 21 & $16.7 \%$ & \multirow{5}{*}{0.019} \\
\hline 2 Years & 13 & $10.3 \%$ & 20 & $15.9 \%$ & \\
\hline 3 Years & 9 & $7.1 \%$ & 9 & $7.1 \%$ & \\
\hline 4 Years & 3 & $2.4 \%$ & 5 & $4.0 \%$ & \\
\hline 5 Years & 1 & $0.8 \%$ & 8 & $6.3 \%$ & \\
\hline \multicolumn{6}{|l|}{ History of Breastfeeding } \\
\hline Not Given Breast Milk & 3 & $2.4 \%$ & 3 & $2.4 \%$ & \multirow[t]{2}{*}{1.000} \\
\hline Given Breas Milk & 60 & $47.6 \%$ & 60 & $47.6 \%$ & \\
\hline \multicolumn{6}{|l|}{ The History of Asthma } \\
\hline Yes & 58 & $46.0 \%$ & 14 & $11.1 \%$ & \multirow[t]{2}{*}{$<0.001$} \\
\hline No & 5 & $4.0 \%$ & 49 & $38.9 \%$ & \\
\hline \multicolumn{6}{|l|}{ Maternal Knowledge } \\
\hline Low & 29 & $23.0 \%$ & 38 & $30.0 \%$ & \multirow{3}{*}{$<0.001$} \\
\hline Medium & 18 & $14.3 \%$ & 2 & $1.6 \%$ & \\
\hline High & 16 & $12.7 \%$ & 23 & $18.3 \%$ & \\
\hline \multicolumn{6}{|l|}{ History of Smoking } \\
\hline Yes & 47 & $37 \cdot 3 \%$ & 21 & $16.7 \%$ & \multirow[t]{2}{*}{$<0.001$} \\
\hline No & 16 & $12.7 \%$ & 42 & $33.3 \%$ & \\
\hline
\end{tabular}




\section{DISCUSSION}

A. The correlation of sex towards the incidences of pneumonia

Based on table 4.8 , the results of the analysis about the correlation of sex towards the incidences of pneumonia presented that there were $57(45.2 \%)$ female patients and 69 (54.8\%) male patients. The results of the analysis explained that there was no significant correlation between sex and the incidences of pneumonia. Toddler boys had a greater chance to suffer from pneumonia than toddler girls because most of the pneumonia sufferers were toddler boys which were 69 (54.8\%).

The results of this study are in line with a study conducted by Jannah (2020), which no correlation between sex and the incidences of pneumonia. Males had the highest number of sufferers which were $52,11 \%$ compared to females. However, statistically, this effect did not have any significant correlation with the incidences of pneumonia.

The results of this study is also supported by a study performed by Yuliani (2016) that boys had more chances to suffer from pneumonia due to the number of the sufferers which were $(38.5 \%)$ compared to girls (11.3\%). However, the results of statistical tests presented that there was a significant correlation between sexes and the incidences of pneumonia in toddlers with $\mathrm{p}=\mathbf{0 . 0 1 2}$. The results of the study conducted by Hartati (2012) also defined that boys were at risk to have pneumonia 1,24 times compared to females. Males were the risk factors that affected pneumonia (Depkes RI, 2004). It occurred due to the diameter of the respiratory tract of boys is smaller than girls or there is a difference in body endurance between boys and girls (Hartati, 2012).

\section{B. The correlation of age towards the incidences of pneumonia}

The correlation of age towards the incidences of pneumonia on toddlers who ever visited
Regional Public Hospital of Lewoleba in 2019.

The results of this study are in line with a study performed by Sumyati (2015) that children aged $<12$ months were at risk to have pneumonia 7.43 times compared to respondents aged $>12$ months. Babies and toddlers have weak endurance compared to adults so that toddlers are categorized as a group that is susceptible to infections such as influenza and pneumonia. Children aged o24 months are more susceptible to suffer from pneumonia than children aged over 2 years. It occurred due to the immunity which was not yet perfect and the respiratory tract was relatively narrow (DepKes RI, 2009). Prematurely born infants (gestational age $<37$ weeks) are at high risk for having diseases related to the immaturity of the CNS (Central Nervous System) and lungs such as aspiration pneumonia due to sucking reflex, swallowing and coughing which are not yet perfect and idiopathic respiratory distress syndrome (hyaline membrane disease). The results of this study implied that the respondents aged $<12$ months were fewer than toddlers aged $>13$ months. However, the age factor was the dominant factor in the incidences of pneumonia in toddlers. Based on this condition, it is very important to maintain the health of children aged $<12$ months by paying attention to proper nutrition and giving immunizations to prevent children from infectious diseases.

\section{The correlation between the history of breastfeeding and the incidences of pneumonia}

The results of the analysis of the relationship between the history of breastfeeding and the incidences of pneumonia in this study found that there were fewer children under five who did not get exclusive breastfeeding which was six toddlers (4.8\%) compared to toddlers who got exclusive breastfeeding which was 120 toddlers (95.2\%). Children under five who 
did not receive exclusive breastfeeding had a greater chance of having pneumonia than those who got exclusive breastfeeding. However, the statistical test results showed that there was no significant relationship between the history of exclusive breastfeeding for infants with the incidences of pneumonia.

Based on the guidelines on lactation management (Ministry of Health, 2010), exclusive breastfeeding means that babies are only given breast milk without any other food or drink, including plain water, except for medicines, vitamins, minerals, and squeezed breast milk. From the 126 respondents, there were only 25 respondents understood how to provide exclusive breastfeeding and most respondents were highly educated. During the interviews, almost all respondents understood the length of time to provide exclusive breastfeeding which was 0-6 months. From the 126 respondents, only six respondents did not provide exclusive breast milk. The category of not giving exclusive breastfeeding was the group that gave predominant breastfeeding (besides breast milk, babies were given a little water or other drinks such as tea ), bottle-feeding (feeding babies with any milk, including milk squeezed by a bottle), artificial breastfeeding ( feeding babies with artificial milk/ formula and not breastfeeding at all), and partial breastfeeding (partly breastfeeding and partly artificial milk/ formula or cereal or other foods).

The nutrients in breast milk correspond to the baby's needs for physical growth and development as well as intelligence. Breast milk contains immunity to protect the baby from allergies. Breastmilk is safe and guaranteed cleanliness because it is directly fed (fed) to the baby in a fresh condition. Breastfeeding is very practical, it never gets spoiled, it has the right temperature and it can be given anytime and anywhere. Breastfeeding can help to improve the baby's suction, swallowing, and breathing reflexes. Therefo- re, exclusive breastfeeding reduces the rate of infant mortality caused by various diseases that commonly affect children such as diarrhea and pneumonia, accelerates recovery from illnesses and helps to reduce the number of births. Infants age under six months who were not exclusively breastfed were five times more likely to die from pneumonia than those who were exclusively breastfed for the first six months of life (UNICEF-WHO, 2006).

\section{The correlation between the history asthma towards the incidences of pneumonia}

The analysis showed that toddlers who had a history of asthma (57.1\%) experienced more pneumonia than toddlers who had no history of asthma 54 (42.9\%). Toddlers who had a history of asthma had a 31,700 times chance of having pneumonia compared to toddlers who did not have a history of asthma. The results of statistical tests showed that there was a very significant correlation between the history of asthma in toddlers and the incidences of pneumonia. The results of this study are in line with the study conducted by Siregar (2020) that children with a history of asthma have a greater risk of having pneumonia than children without a history of asthma. This was because children with a history of asthma had a risk of having defective respiratory tract, impaired integrity of mucus and ciliated cells, and decreased local and systemic humoral/cellular immunity. Dawood (2010) explained that children with asthma could have an increased risk of having pneumonia as a complication of influenza. Infants and children aged under five years were at higher risk of developing pneumonia as a complication of influenza when hospitalized. The results of this study implied that children with a history of asthma had a significant relationship with the incidences of pneumonia. 


\section{E. The correlation between the level of maternal knowledge towards the in- cidences of pneumonia}

Based on table 4.12, the results of statistical tests using the Chi-square test between the variable of the history of asthma and the incidences of pneumonia obtained a $\mathrm{p}<0.001$, so it could be interpreted that there was a significant relationship between the level of maternal knowledge and the incidences of pneumonia in toddlers who ever visited Lewoleba Hospital in 2019.

Based on the results of the analysis of the correlation between the level of maternal knowledge and the incidences of pneumonia in this study, there were 67 mothers of toddlers who had low knowledge (53.2\%) which was more than mothers who had moderate knowledge were 20 people (15.9\%) and mothers who had high knowledge were 39 people (31.0\%). Mothers of toddlers with low knowledge had a chance of their toddlers to experience pneumonia 0.971 times compared to mothers with high knowledge. However, the results of multivariate analysis showed if there was no relationship between the level of maternal knowledge and the incidences of pneumonia marked with $\mathrm{p}=0.924$.

Based on the facts in the study sites, the respondents' lack of knowledge about pneumonia in the Lewoleba Regional Hos-pital was affected by several supporting factors, such as the respondent's education level and the respondent's occupation. The low knowledge of respondents about pneumonia occurred due to the lack of health news that had to be provided by health workers to respondents during Integrated Healthcare Center activities or other health counseling activities, and the late information which the respondents got when their toddler became a pneumonia sufferer.

Jannah et al. (2020) explained that maternal knowledge had no significant relationship with the incidences of pneumonia with $\mathrm{p}=0.480$. In contrast to the results of the study performed by Fitrianti (2018) that knowledge had a significant relationship with the incidences of pneumonia. One of the things that affect the behavior or actions of a person is knowledge in which the increase of knowledge has a positive relationship with behavior. Mothers with a higher level of maternal knowledge about pneumonia had lower chances of children suffering from pneumonia. Mother with lower the level of maternal knowledge had a higher possibility of children suffering from pneumonia.

\section{F. The correlation between the history of smoking towards the incidences of pneumonia}

The results of the analysis of the correlation between smoking habits of family members showed that toddlers with smoking family members in the house had a higher number which was 68 (54.0\%) compared to toddlers with non-smoking family members in the house which were $58(46,0 \%)$. Toddlers with smoking family members in the house have a chance of experiencing pneumonia 2.857 times compared to toddlers who lived with non-smoking family members in the house.

The results of this study are in line with the study carried out by Hasnawati et al. (2018) that toddlers who lived in a house with family members who smoked in the last month had a greater risk of having pneumonia than toddlers who lived at home whose family members did not smoke in the last month. This could be inferred that cigarette smoke is a risk factor for pneumonia in toddlers.

Pratiwi (2018) showed that there was a significant relationship between toddlers who lived in the same house with the smoking family members and the incidences of pneumonia. The toddlers had a risk of having pneumonia 1.83 times compared to toddlers who live in the house with non-smoking family members. The behavioral factor that 
affected the incidences of pneumonia in toddlers was the smoking habit of family members. The greater the number of cigarettes smoked by family members, the greater the risk of respiratory problems, especially in infants and children.

\section{AUTHOR CONTRIBUTION}

Nikosius Dae Sory Wutun, M Dinah Charlota Lerik, and Muntasir arranged the research plan, collected data, analyzed data, and wrote the script.

\section{CONFLICT OF INTEREST}

This study did not have any conflict of interest.

FUNDING AND SPONSORSHIP

This study used personal funding.

\section{ACKNOWLEDGEMENT}

The researcher would like to thank all of the respondents, the government of Lewoleba city, and Regional Public Hospital of Lewoleba who welcomed the researchers and prepared the data required by the researchers.

\section{REFERENCE}

Anwar A, Damayanti I (2014). Pneumonia pada anak balita di Indonesia. Jurnal Kesehatan Masyarakat Nasional.8(8): 359-365. http://dx.doi.org/10.21109/kesmas.v8i8.405.

Dawood OT, Ibrahim MIM, Palaian S (2010). Parent's knowledge and management of their children's ailments in Malaysia. Pharmacy Practice.8(2):96102. Retrieved from: http://scielo.isciii.es/pdf/pharmacy/v8n2/original2.pdf.

Departemen Kesehatan RI (2004). Pedoman Program Pemberantasan Penyakit Infeksi Saluran Pernapasan Akut (ISPA) untuk Penanggulangan Pneumonia pada Balita. Jakarta: Depkes RI.
Departemen Kesehatan Republik Indonesia (2009). Pedoman pengendalian penyakit infeksi saluran pernafasan akut, direktorat jendral pengendalian penyakit dan penyehatan lingkungan.

Departemen Kesehatan Republik Indonesia (2010). Manajaemen laktasi: Buku panduan bagi bidan dan petugas kesehatan di puskesmas. Jakarta: Direktorat gizi Masyarakat.

Dinas Kesehatan Kabupaten Lembata (2017). Profil Kesehatan Kabupaten Lembata tahun 2017. Lembata: Dinas Kesehatan Kabupaten Lembata.

Dinas Kesehatan Provinsi Nusa Tenggara Timur (2017). Profil kesehatan Provinsi Nusa Tenggara Timur.

Fitrianti S (2018). Hubungan pengetahuan ibu dengan kejadian pneumonia pada balita di Puskesmas Kebun Handil Kota Jambi.Jurnal Akademika Baiturrahim Jambi. 7(2): 108-113.http://dx.doi.org/10.36565/jab.v7i2.74.

Hartati S, Nurhaeni N, Gayatri D (2012). Faktor risiko terjadinya pneumonia pada anak balita. Jurnal Keperawatan Indonesia. 15(1): 13-20.http://dx.doi.org/10.7454/jki.v15i1.42.

Hasnawati H, Sudirman S, Afni N (2018). Faktor yang berhubungan dengan penyakit pneumonia pada anak balita di RSUD Mokopido Kabupaten Tolitoli. Jurnal Kolaboratif Sains.1(1): 350-359. http://dx.doi.org/10.31934/jom.v1i1.367.

Jannah M, Abdullah A, Hidayat M, Asrar Q (2020). Analisis faktor risiko yang berhubungan dengan kejadian pneumonia balita di wilayah kerja UPTD Puskesmas Banda Raya Kota Banda Aceh Tahun 2019. Jurnal Kesehatan Masyarakat Aceh. 6(1): 20-28.

Kementerian Kesehatan Republik Indonesia (2018). Data dan informasi profil kese- 
Wutun et al./ Risk Factors of Pneumonia in Children under Five

hatan Indonesia 2017. Jakarta: Kementerian Kesehatan RI.

Najimi A, Dolatabadi NK, Esmaeili AA, Sharifirad GR (2013). The effect of educational program on knowledge, attitude, and practice of mothers regarding prevention of febrile seizure in children. Journal of Education and Health Promotion: 2(26). doi: 10.4103/22779531.112703.

Novrianda D, Lucida H, Soumariris I (2015). Perbandingan efektivitas pendidikan kesehatan terhadap pengetahuan dan kemampuan ibu merawat balita ISPA di Puskesmas Padang Pasir dan Pauh. Jurnal Sains Farmasi dan Klinis. 1(2): 159-169. http://dx.doi.org/10.29208/jsfk.2015.1.2.29

Pratiwi DS, Yunus M, Gayatri RW (2018). Hubungan antara faktor perilaku orang tua dengan kejadian pneumonia balita di wilayah kerja Puskesmas Dinoyo Kota Malang. Preventia: The Indonesian Journal of Public Health 3(2): 102130.http://dx.doi.org/10.17977/umo44v3i2p102-130.

Siregar DA (2020). Faktor-faktor yang berhubungan dengan kejadian pneumonia pada balita di Rumah Sakit Umum Daerah (RSUD) Kota Padangsidimpuan tahun 2020. Jurnal Ilmiah Kohesi. 4(2): 9. Retrieved from: https://kohesi.sciencemakarioz.org/index.php/JIK/article/view/122.

Taqiyyah B, Jouhar M (2013). Asuhan keperawatan: Panduan lengkap menjadi perawat profesional jilid 1. Jakarta: Prestasi Pustakaraya.
Wahyuningsih HS, Puspitaningrum D, Anggraini NN (2014). Hubungan persepsi ibu tentang peran serta tenaga kesehatan dengan perilaku pencegahan pneumonia pada ibu balita usia 0-5 tahun di Puskesmas Ngesrep Kota Semarang. Jurnal Universitas Muhammadiyah Semarang. 3(1): 24-29. https://doi.org/10.26714/jk.3.1.2014.24-29.

WHO (2006). Pneumonia: the forgotten killer of children. Retrieved from: https://www.who.int/maternal_child_adolescent/documents/9280640489/en/. WHO (2016). Pneumonia. Retrieved from: https://www.who.int/news-room/factsheets/detail/pneumonia. Diakses Oktober 2019.

Yahaya AK, Ekpenyong BN, Obegu P (2018). Caregiver's knowledge of pneumonia and uptake of vaccination in under five children in Kaduna State, Nigeria. J Med Biomed Sci. 7(1): 40-48. Retrieved from: https://www.ajol.info/index.$\mathrm{php} / \mathrm{jmbs} /$ article/view/172462.

Yuliani E, Nurhaeni N, Waluyanti FT (2016). Perencanaan pulang efektif meningkatkan kemampuan ibu merawat anak dengan pneumonia di rumah. Jurnal Keperawatan Indonesia. 19(2): 121-127. http://dx.doi.org/10.7454/jki.v19i2.461.

Zar HJ, MadhiSA, Aston SJ, Gordon SB (2013). Pneumonia in low and middle income countries: progress and challenges. Thorax. 68(11):1052-6. doi:10.1136/thoraxjnl-2013-20424 